\title{
Postcolonialism and Socio-political Development in Africa: Learning Through the Literary Eyes of Ngugi Wa Thiong'O
}

\author{
Adam, Ezinwanyi E. \\ Babcock University, Ilishan-Remo, Nigeria
}

\begin{abstract}
This study presents the fact that the relationship between the white colonialists and the black indigenous population threw up a myriad of socio-political cross fertilization in Africa. The way and manner the Whites related with the Black people, the levels of reactions and response of the black population to the invading socio-political values and standards during the colonial era has been the subject of interesting writings in Africa. Of significance in this class of writing in Kenya is Ngugi Wa Thiong'O’s works. His profound sympathy with his people in their weaknesses, their poverty in the socio-political development in Kenya, and particularly his hatred of exploitation, cruelty, and injustice are noteworthy. It is the thrust of this work to critically look at the socio-political change in postcolonial Kenya through the literary eyes of Ngugi in his remarkable and compelling work, Petals of Blood (1977), with a view to establish the contributions of the work to real socio-political development in Kenya through the approaches of textual criticism, interpretation, and post-colonial theory. Thus, the study examines the socio-political development in postcolonial Kenyan society, the lifestyle of people, and the relationships that exist among Kenyan citizens, especially between the rich and the poor, the government (ruling class), and the governed (masses). It also establishes the basis for the continued prevalence of the themes of violence, corruption, injustice, disillusionment, decadence, and disintegration in contemporary Kenyan literature, in spite of the transformation and change in the socio-political setting of the State.
\end{abstract}

Keywords: post-colonialism, literature and post-colonial theory

\section{Introduction}

It is no longer news that the colonial or imperial powers from Europe had colonized most parts of the African continent and other parts of the world. It is also indisputable that the colonial masters, including the English and the French, had in the process of colonization, seriously impacted on and radically altered the socio-political make-up of the African communities and their populations. What may be in controversy may be the extent or degree of the continuing pointing of accusing fingers at several factors of socio-political decadence like corruption, violence, injustice, cruelty, exploitation, and hatred prevalent in many African nations as being a direct consequence of the pervading impact of colonialism. In countries like Nigeria, Ghana, Uganda, and Kenya, the British imperial policies have been held responsible for the delayed or near collapsed socio-economic and political transcendence to levels of developed economies. To what extent, this may be true forms part of the thrust of this work.

In Kenya, particularly, the manner and style of the relationship of the white colonialists with the Kenyan

Adam, Ezinwanyi E. Ph.D., Lecturer, Department of Languages and Literary Studies, Babcock University. 
population, the levels of reactions and responses of the Kenyan population to the invading socio-political orientations of the colonial officers have formed the subject of interesting writings in literature. Amongst such writings, the works of Ngugi wa Thiong'O occupy a prominent position. Ngugi's Petals of Blood, published in 1977, particularly captures the socio-political climate of the postcolonial era in Kenya. It provides a rich literature through which socio-political developments, post-colonialism, have been recorded. It is, therefore, the intention of this work to critically analyse the socio-political changes in post-colonial Kenya through the literary eyes of Ngugi in Petals of Blood.

\section{Post-colonialism in Africa}

Post-colonialism refers to the regime of knowledge or studies pertaining to the impact or implications or effects of colonialism on erstwhile colonial enclaves after the end of the colonial relationship or after the beginning of national sovereignty. Colonialism hardly requires much clarification as it represents one of the ubiquitous political practices in most parts of Africa in the last forty to fifty-five years. As a brand of governance, it represents the taking over or usurpation of political independence of the indigenous population of a given State by a foreign power or State, in such a manner that the colonized territory is politically and territorially annexed to the territory and the system of the colonizing power or nation. A classical example of colonization is the colonization of Nigeria by Britain (1914-1960).

To understand post-colonialism, it is imperative to analyse the pre-independence socio-political status and contrast it with the era immediately preceding the attainment of political and territorial independence. The activities of the State, the economic, socio-political values of the citizens, the reactions and responses of the State apparatus, and the citizenry to the reality of self-rule at the end of colonialism all constitute the vast field of post-colonialism.

Before independence, most colonial territories depended almost absolutely on the political, economic, and socio-cultural directions and guidance of the imperial state for the determination of their affairs. The colonial power determined the political structure, the style or system of government, the nature of the constitution and the political processes for the colonized territories. Economically, the ideological disposition of the controlling colonial State became the prescriptions for the economies of the colonial territories. For instance, whether the colonial territory was to apply capitalist's conceptions, or socialist's inclinations, or a mixed economy, was all to be determined by the controlling colonial power. Socio-cultural colorations of the colonized territories were intricately attached to the socio-cultural values and standards of the colonizing power. Therefore, the determination of virtually most spheres of political, economic, socio-cultural, and even religious life of the colonies were directly controlled by the colonizing power (Said, 1993; Mark, 2007).

It is, therefore, from this background that the euphoria in the colonized territories, in reaction to the attainment of state sovereignty, was palpable. Suddenly, there was an almost complete turnaround in the controls and determination of the political, economic and socio-cultural lives of the colonies, from the white foreign domination to black indigenous appropriation of self-rule. The ecstatic reaction of the indigenous population, however, had left the indigenous population hardly prepared for the massive gaps between expectations of political, economic, and social national transcendence, and the realization of such political Eldorado.

The high levels of political corruption, violence, decadence, governmental ineptitude, and nepotism have characterized the post-colonial experiences of most African nations (Irele, 1981; Mark, 2007). This scenario 
has been captured by not a few African authors, including Ngugi wa Thiong'O in his novel, Petals of Blood. It is apposite to undertake an appraisal of the literary concerns of post-colonialism as a theory.

\section{Literature and Post-colonial Theory}

Postcolonial literature refers to writings by people from formerly colonized countries. According to Ashcroft, Griffiths, and Tiffin's influential formulation in 1989, the term "post-colonial" covers "all the culture affected by the imperial process from the moment of colonization to the present day. This is because there is a continuity of preoccupation throughout the historical process initiated by European imperial aggression” (p. 2). Postcolonial literary theory, according to the observation made by Mark (2007), emerges from the inability of Euro-American theory to escape false notions of "the universal”. Euro-American historiography, philosophy, and literary study assume that many values and value-assigning practices, epistemologies, characteristics of language, genres, psychological and social models, and the like, apply across time and place. Therefore, postcolonial theory attempts to deconstruct and reconstruct such assumptions not only through contesting them but also through developing or rediscovering indigenous theories of value, language, and others. However, the study identifies five main models of approaches of postcolonial theory, which are as follows.

National or regional models emphasize distinctive features of national or regional history and culture. Examples are the Subaltern Studies group in India, which re-inscribes history from the position of previously silenced indigenous people, and many types of Caribbean studies, which look at shared features, namely, the legacy plantation and slavery, that have shaped literary culture in neighbouring islands (Mark, 2007).

Racial or Ethnic models are not necessarily tied to an essentialist view of race, but rather to the notion that "the idea of race" has been a major feature of Euro-American economic, political, and cultural practice. Examples are writings by African and African-Diaspora authors.

Comparative models often stress stylistic and thematic concerns that traverse nation and region. A major concern is language, not only how English or other European languages supplant indigenous languages, but also how English or European languages change into a "nation-language". Another major concern is the struggle oppression. It also focuses on concepts such as exile, education, and treatment of women.

As observed, the ethnicity and comparative models are very much applicable to the study of Ngugi's novel, where there is discrimination against the poor and lowly (represented by Wanja, Abdulla, Karega, Nyakinyua and others) by the rich (represented by Kimeria, Chui, and Mzigo). There is also racial discrimination against blacks by the whites as represented by the students and the Principal, respectively, of the high school in the city, attended by Munira. The comparative model is used for the analysis of themes and visions portrayed in Petals of Blood.

Colonizers/colonized models concentrate on the imperial-colonial dialectic. One interesting question such theorists ask is whether decolonization is ever possible. Fanon, the "founding father" of this postcolonial theory, wondered whether "the native intellectual" could escape the hegemony of colonizing, and/or neo-colonizing culture.

Finally, the Hybridity/syncreticity models are mostly influenced by post-structuralist theories. They often deconstruct the binary opposition of center/periphery, master/slave, colonizer/colonized, civilization/savagery, rich/poor, etc. The "other" is expedient in this sort of postcolonial theory. According to Ashcroft, Griffiths and Tiffin (1998, pp. 169-71), the "other" is anyone who is separate from one’s self. The existence of others is vital in defining what is "normal” and in situating one's own place in the world. In postcolonial theory, as observed, 
"the other" can refer to the colonized others who are marginalized by the imperial discourse, identified by their difference from the centre and, perhaps importantly, become the pivot of anticipated mastery by the imperial "ego".

The Hybridity model is, however, explored in Petals of Blood, to show how much influence the colonizers or western culture still has on the colonized or African culture, even as an independent nation. Thus, the Ethnicity, Comparative, and Hybridity models are most relevant to this study and are applied in the textual analysis of the selected novel to bring out the themes of betrayal of love, exploitation, violence, oppression, and death, which all depict the high level of decadence and disintegration in most African nations.

\section{Ngugi wa Thiong'O's Petals of Blood}

The story in Ngugi wa Thiong'O's Petals of Blood, though narrated mostly in the form of reminiscences rather than in flashbacks, begins in the present with the arrest of the four major characters-Munira, Karega, Wanja, and Abdulla. Munira, a school teacher at New Ilmorog Primary School, is the first to be arrested by two police men in what they claim to be a routine questioning about a murder case in Ilmorog. Next to be arrested is Abdulla who lives at New Jerusalem in Ilmorog, Wanja then follows, and finally, Karega who works at the Theng'eta Brewery in Ilmorog. They are arrested as suspects in the murder case of three African directors of the Theng'eta Brewery—Mzigo, Chui, and Kimeria.

The story is narrated in the form of Munira's recollections as he sits in his cell, writing notes in the form of a dairy in order to keep his mind clear about the importance of the incidents, past and present in Ilmorog and to satisfy the probing mind of the police investigator and his several demands. This, according to Adam (2013), affects the narrative technique as the story moves from the present (told in the omniscient point-of-view) back to the past, twelve years to Munira's reminiscences of his first arrival in Ilmorog, events and stories that lead to change and development of Ilmorog (told in the first person point-of-view).

Munira, at his first arrival to Ilmorog — a village which was occupied by peasant farmers and their uneducated children who only stay to help their parents in farm work and cattle rearing, tries to reorganize a school for the children. He is met with difficulty as the children refuse to come to school and hatred, perhaps, because he is seen as an agent of social change that comes with colonialism and post-colonialism, as well as imperialism.

The school was a "four-roomed barrack with broken mud walls, a tin roof with gaping holes and more spiders' webs and the wings and heads of dead flies” (Ngugi, 1989, p. 5). Many teachers who had been sent to Ilmorog before the arrival of Munira had encountered similar challenges and gone away without notices. Munira, therefore, is expected to leave like the others, but he does not. He shares his experiences with Abdulla, Wanja and later on, with Karega, who had all come to Ilmorog—a deserted homestead for reasons well known to them as individuals.

Abdulla is handicapped and relies on his donkey for his movement. He lost the use of one of his legs during his involvement as a Mau Mau fighter in the fight for "Mhuru"-freedom of the Kenyan people from white colonialists. He and his friend, Nding'uri who happens to be an elder brother to Karega, are betrayed by Nding'uri's girlfriend's brother, who they later found out to be Kimeria, one of the directors of Theng'eta Brewery. It is also Kimeria who destroys Wanja. Wanja is impregnated by Kimeria, a married man with two children, who denies the pregnancy. She gives birth to a baby who she later drops into a pit toilet. She is hunted by the memory of her past and in order to forget her past and live a new life, she comes to live in Ilmorog with her 
grandmother, Nyakinyua who is a strong-spirited, friendly, and influential old woman. She counsels Munira, Abdulla, Karega, and Wanja and also gives them all the support they need during the journey to the city on an account of the drought in Ilmorog.

Munira is seen as a big failure in his own family and a coward by his friends as he refuses to take the right actions but always chooses to sit on the fence. He is seen as an outsider. His siblings happen to be very successful people. They are all doing well in their respective endeavours of life. Munira's father, Ezekieli is “"tall, severe in his austere" and "a wealthy landowner and a respected elder in the hierarchy of the Presbyterian Church" (Ngugi, 1989, p.13). He believes that children should be brought up on "boiled maize grains sprinkled with a few beans and on the tea with only tiny drops of milk and no sugar, but all crowned with words of God and prayers” (Ngugi, 1989, pp.13-14).

To whom much is given, much is expected. Ezekieli, therefore, expects so much from Munira, his eldest child, whom he had given much. Munira disappoints his father when he is expelled from school for taking part in a revolt. While his siblings (except for Mukami, Karega's girlfriend who commits suicide) become successful professionals and financially independent, Munira still wallows in poverty as he cannot attend to his needs and wants with his little earnings as a teacher in a "village-turned-city", Ilmorog. Munira, however, enjoys his work and experience as a teacher. After all, he is not a total failure, as his father thinks, since he contributes so much to the society by giving education to impoverished children of Ilmorog. He teaches them the names of the parts of flower, "the stigma, the pistil, pollen, the petals" (Ngugi, 1989, p. 21). It is while Munira is teaching the children about fertilization that a child cries out, "Look. A flower with petals of blood" (Ngugi, 1989, p. 21), referring to a solitary red bean flower in a field dominated by white, blue and violet flower.

Munira falls in love with Wanja, a strong, resourceful, intelligent, and dynamic woman whose ugly experiences in her early age as a beautiful young girl turns her into prostitution. He is attracted by Wanja's beauty and often sees her in his dreams. Wanja sleeps with Munira, not out of love but in order to be impregnated by him. But that does not happen as she did not conceive. Wanja meets Kimeria again, after a long time, during their journey to the city. He forces her to sleep with him, thereby humiliating her once again. This experience hurts Wanja who then swears to get back at Kimeria. During the journey, so many personal secrets are revealed by Abdulla, Karega, Wanja, and Munira. It is at this time that Wanja reveals her relationship with Kimeria as well as other men like Kalasingh, a white man who wanted her to sleep with a dog. She explains how Kimeria, like his contemporaries, had taken advantage of her as a maid in his household. Abdulla also reveals how he fought as a guerilla fighter; he worked with Ole Massai who was killed in the fight for freedom and also with Dedan Kimathi.

The journey, therefore, becomes a journey of discoveries of self, potentials, abilities, strengths, talents, and weaknesses. They meet with several challenges, hunger and thirst, as well as with self-centered, arrogant, abusive and power drunk Reverend Jerrod Brown Kamau, Raymond Chui, Kimeria, and Nderi wa Riera, the Member of Parliament (MP) for Ilmorog, but at last, overcome. They experience victory through the help of the lawyer in Nairobi West, Wanja's friend who is an embodiment of truth, self-sacrifice, kindness, honesty, and true patriotism.

Karega and Wanja start a relationship during the journey, and for the first time, Wanja falls in love with a man, Karega, who she wants to spend the rest of her life with. Munira gets envious of Karega and gets him dismissed from his teaching job in Ilmorog. Karega also finds out that Wanja is a mistress to Kimeria wa Kamianja, the man who betrayed Nding'uri, his brother and Abdulla; the man who is responsible for Abdulla's crippled state. He leaves Ilmorog unannounced and later returns a different and experienced man. He comes back 
to find a fast developing Ilmorog with so many changes on the people and the entire town.

The change affects everybody—Abdulla, Wanja, Munira, Njuguna, and Nyakinyua whose death is as a result of the change that has come to Ilmorog. Munira explains that, "Indeed, changes did come to Ilmorog, changes that drove the old one away and ushered a new era in our lives. And nobody could tell, really tell, how it had happened, except that it had happened” (Ngugi, 1989, p. 280). The change affects Munira psychologically, spiritually, economically, and physically. He becomes a religious fanatic after his unconvincing and rather too sudden conversion after an encounter with Prophetess Lillian, his former lover. The story ends with Munira's confession to setting Wanja's whorehouse on fire in order to save Karega from the claws of Wanja. In the process, he kills Chui, Kimeria, and Nderi, the symbols of imperialist government in Africa. He also hurts Wanja (Adam, 2013).

\section{Post-colonial Issues and Socio-political Changes in Kenya: An Analysis of Petals of Blood}

Ngugi wa Thiong'O's Petals of Blood has been said to be his most representative, ambitious, and comprehensive novel because it incorporates all the major thematic preoccupations of his novels, and African novels, from the pioneers, that is the first generation, to the contemporary novelists, that is twenty-first century African novelists (Palmer, 1979). The novel is concerned with the first stage of the African historical development with its dominant themes of cultural imperialism, racial discrimination and exploitation of the African continent by white colonialists. It focuses mainly on the disintegration and disillusionment caused within the indigenous African society by civilization through the introduction of foreign or strange educational, political and religious systems by white colonialists (Palmer, 1979, pp. 68-9).

Ngugi weaves into his story the Kenyan history of the first white colonist to bring the so-called civilization. Lord Freeze Kilby comes with his wife to civilize Ilmorog. He employs the use of force, aggression, and oppression, on one hand, and religion and education, on the other hand. Munira explains that:

Cambridge Fraudsham came to the scene. Before we had any time to know him, he changed our lives. Fresh from the war, he already had firm notions how an African school had to be. Now, my boys, trousers are quite out of the question in the tropics. He sketched a profile of an imaginary thick-lipped African in a grey woolen suit, a sun-helmet, a white starched stiff collar and tie, and laughed contemptuously: Don't emulate this man. There was to be no rice in our meals: the school did not want to turn out men who would want to live beyond their means. And no shoes, my boys, except on the day of worship: the school did not want to turn out black Europeans but true Africans who would not look down upon the innocence and simple ways of their ancestors. At the same time, we had to grow up strong in God and the Empire. It was the two that had rid the world of the menace of Hitler.... We saluted the British flag every morning and every evening to the martial sound from the bugles and drums of our school band. Then we would all march in orderly military lines to the chapel to raise choral voices to the Maker: Wash me, Redeemer, and I shall be whiter than snow. We would then pray for the continuation of an Empire that had defeated the satanic evil which had erupted in Europe to try the children of God. (Ngugi, 1989, pp. 28-9)

Education and religion are described as powerful tools of western civilization not just in Kenya but in the entire Africa during the colonial period. Ngugi employs the use of historical facts to tell the story of how whites came to settle in Ilmorog and how they introduced strange things, including food and motor car in Ilmorog (Ngugi, 1989, pp. 120-22). The novel also projects the second stage of Kenyan history, that is, the Mau Mau fight for freedom. Ngugi tells the story of historical figures like Dedan Kimathi, Ole Masai, and other Mau Mau fighters and their struggle for liberation. Thus, he projects the themes of oppression, war, and struggle for liberation of African nation and people, revolution, man's inhumanity to man, disillusionment as a result of 
unrealized dreams and hopes, betrayal, and disintegration of the indigenous African society (Ngugi, 1989, p. 141).

Petals of Blood reveals the third stage of historical development in Kenya and in extension, Africa as a continent, with its attending themes such as poverty, prostitution, class, corruption, exploitation, betrayal, social injustice, decadence, hypocrisy, feminism, imperialism, and many other postcolonial issues. The novel presents, according to Palmer (1979), "the most comprehensive analysis to date of the evils perpetrated in independent African society by black imperialists and capitalists” (p. 288). For example, it is observed that things in Ilmorog and Kenya as a nation have not been better even as African governors and chiefs take over the leadership of the state. We are told that since they took over the "people were threatened by lack of water; lack of roads; lack of hospitals” (Ngugi, 1989, p. 85).

Ngugi's novel also focuses on the resourceful and courageous African women, old and new, as represented by Nyakinyua and Wanja, respectively. Wanja is the most significant female character in the novel. She is also seen as the most influential woman in Ilmorog. Munira tells Karega that

She is the most powerful woman in all Ilmorog. She owns houses between here and Nairobi. She owns a fleet of matatus. She owns a fleet of big transport lorries. She is that bird periodically born out of the ashes and dust. (Ngugi, 1989, p. 281)

Wanja's driving force, as discovered throughout the novel, is the need to be independent and not to enslave men. She channels all energy, courage, resourcefulness, dynamism, and strength towards making herself independent. It is her energy, initiative, resourcefulness, creativity, and drive, which we admire so much in the novel, that bring development in Ilmorog. She learns from her father that, "Money moves the world. Money is time. Money is beauty. Money is elegance. Money is power" and that with money one can buy freedom for all people because “money is freedom” (Ngugi, 1989, p. 233). Therefore, Wanja works hard to bring progress not just for herself but for the whole of Ilmorog and the change did come. The text affirms:

Indeed, changes did come to Ilmorog, changes that drove the old one away and ushered a new era in our lives. And nobody could tell, really tell, how it had happened, except that it had happened. Within a year or so of the New Ilmorog shopping centre being completed, wheat fields and ranches had sprung up all around the plains: the herdsmen had died or had been driven further afield into the drier parts, but a few had become workers on the wheat fields and ranches on the earth upon which they once roamed freely. The new owners, master-servants of bank power, money and cunning, came over at weekends and drove in Land rovers or Range Rovers, depending on the current car fashion, around the farms whose running they had otherwise entrusted to paid managers. The peasants of Ilmorog had also changed. Some had somehow survived the onslaught. They could employ one or two hands on their small farms. Most of the others had joined the army of workers who had added to the growing population of the New Ilmorog. But which New Ilmorog? (Ngugi, 1989, p. 280)

Ngugi explains that the growth and development of the community have resulted to the creation of several phases of Ilmorog, which completely change the communal way of living of the people of old Ilmorog and bring the individualistic, class and exploitative style of living that come with capitalism. According to the narrator:

One was the residential area of the farm managers, County Council officials, public service officials, the managers of Barclays, Standard and African Economic Banks, and other servants of state and money power. This was called Cape Town. The other — called New Jerusalem — was a shanty town of migrant and floating workers, the unemployed, and the prostitutes and small traders in tin and scrap metal. Between the New Jerusalem and Cape Town, not far from whose Mwathi had once lived guarding the secrets of iron works and native medicine, was All Saints church, now led by Rev. Jerrod Brown. Also somewhere between the two areas was Wanja's Sunshine Lodge, almost as famous as the church. (Ngugi, 1989, pp. 280 -1) 
The change affects everyone in Ilmorog, as well as the community itself. Nyakinyua's death is as a result of the change in the society; she could not reclaim her land that was taken away from her by the bank (Ngugi, 1989, p. 275). Abdulla loses everything, including his donkey and bar. He becomes a road-side seller of oranges. Munira becomes a religious fanatic. Karega becomes a trade union activist, organizing workers and the masses to restore the lost African societal values.

In Part One, Ngugi presents a community that represents a typical small traditional rural community with its innocence and purity intact. In Part Two, at the start of the journey to the city in search of solution to the drought, Ngugi, making use of African oral traditions, celebrates the heroes of Ilmorog revealing the gradual social change from a nomadic to an agrarian culture, and presenting their source of pride, joy, unity, and contentment. The introduction of imperialism and capitalism by not just whites but also blacks (indigenes) was the first blow to Ilmorog's pride, joy, and unity; this consequently led to the death of cultural and traditional values, the social, moral, and political decay and disintegration of Ilmorog community (Adam, 2013).

At the beginning of the novel, Ilmorog is described as a desolate, unattractive, and unprogressive rural community with broken mud walls, a tin roof with gaping holes and more spiders' webs and the wings and heads of dead flies. No wonder teachers refuse to come to Ilmorog and those who came "ran away at the first glance" (Ngugi, 1989, p. 5). Even the young people of Ilmorog are happy to run away from the community:

Our young men and women have left us. The glittering metal has called them. They go, and the young women only return now and then to deposit the newborn with their grandmothers already aged with scratching this earth for a morsel of life...The young men also. Some go and never return. Others sometimes come to see the wives they left behind, make them round-bellied, and quickly go away as if driven from Ilmorog by Uhere or Mutung'u. (Ngugi, 1989, p. 7)

The general comment was "Who would want to settle in this wasteland except those without limbs-may the devil swallow Abdulla — and those with aged loins—may the Lord bless Nyakinyua, the old woman” (Ngugi, 1989, p. 5). It is, therefore, noteworthy that the only young people who stay in Ilmorog are the spiritually maimed ones as symbolized by Abdulla's lame leg. Munira is staying in Ilmorog to hide from the competitive capitalist society; Abdulla is maimed during the Mau Mau fighting for liberty and he is disillusioned by the result of the Uhuru -independence of Kenya. Wanja is running away from her life as a prostitute and searching for self-fulfillment in motherhood, and Karega who is expelled from school and is unable to survive the oppressive capitalist Kenya, and finally, the wise old people as represented by the strong-spirited Nyakinyua and Njuguna. Ilmorog is described as "a 'deserted homestead', 'a forgotten village', an island of underdevelopment which after being sucked thin and dry was itself left standing static, a grotesque distorted image of what peasant life was and could be" (Ngugi, 1989, p. 184).

The journey to the city finally brings to result rapid development and evident transformation in Ilmorog which is suggested by the symbol of rain - the rain that falls immediately after their journey to the city is to the elders of Ilmorog, an answer to their sacrifice. Ngugi makes use of images of the earth's reception of the rainfall to suggest productiveness, bountiful harvest and fruitfulness. Some of the images are got from oral traditions of folktales (Ngugi, 1989, p. 196).

Even the maimed souls of individuals are revived by the rain-spirit. "Wanja was possessed of the rain-spirit. She walked through it, clothes drenched, skirt-hem tight against her thighs, reveling in the waters of heaven" (Ngugi, 1989, p. 196). Despite all the happiness and joys that came with the rain, people still had their doubts about what would follow or happen afterwards, whether it would be favourable or not. Their doubts are, therefore, 
justified as capitalists move into Ilmorog with their industries, banks, roads, factories, shops, breweries, hotels, and estate management. The old small village of Ilmorog is completely and irredeemably destroyed by the change that comes with modern civilization.

The people of Ilmorog who are mainly peasants, unable to compete or contest with the business insights and expertise of the capitalists, painfully lose their lands and inheritances, and finally, disintegrate dependently into labourers or worse, for example, becoming roadside orange sellers like Abdulla. Some courageous ones, like Nyakinyua, who are determined to fight all forces of capitalism and exploitation, are discouraged by the lack of support they get. We, therefore, agree with Killam (1973), Moore (2000), and Palmer (1979) that Nyakinyua's resolution constitutes the last failing attempt of a once venerable and protected society to resist the encroachments of strange men (Adam, 2013).

However, this attempt fails because of the lack of support received from others which signifies the degeneration that has taken over the whole of Ilmorog as a result of corruption, social and moral decadence, and all other attendant problems of capitalism, including lack of housing (shelter), water, clothing, security, and food - the primary needs of man. Ngugi also emphasizes the point that this degeneration was caused first by the white imperialists during the colonial stage and the black imperialists after independence. These people pile up wealth and neglect the needs of the people and their responsibilities toward them. They rather invite the masses for a cultural programme and for teas which they are tasked financially in order to participate (Ngugi, 1989, pp. 84-9).

\section{Conclusion}

This work has considered post-colonialism and its impact on socio-political development in Africa as reflected in Ngugi's Petals of Blood. It has identified the socio-political crisis prevalent in post-colonial Africa such as violence, corruption, insecurity, unemployment, nepotism, imperialism, among others. This crisis is contradistinguished from the high political, economic and social expectations at the point of attainment of sovereignty from the British colonial masters. Ngugi captures these political and economic failures in his novel, where he clearly shows that colonialism and post-colonialism have impacted greatly on the negative socio-political score card of nascent African nations after the attainment of independence.

\section{References}

Adam, E. E. ( April 2013). The Foundations of Literary Excellence in the Selected Novels of Fyodor Dostoyevsky, Leo Tolstoy, Ben Okri and Ngugi wa Thiong'O (Ph.D. thesis, Department of Languages and Literary Studies, Babcock University). Ashcroft, B., Giffiths, G., \& Tiffin, H. (1989). The empire write back. London and New York: Routledge.

Ashcroft, B., Giffiths, G., \& Tiffin, H. (1998). Key concepts in post-colonial studies. London and New York: Routledge.

Griffiths, G. (2000). African literatures in English: East and west. Harlow, Essex: Pearson Education.

Irele, A. (1981). The African experience in literature and ideology. London: Heinemann Educational Books Ltd.

Killam, G. D. (Ed.). (1973). African writers on African writing. London: Heinemann.

Mark, E. O. (2007). Decadence and disintegration: A postcolonial study of selected new Nigerian novels (Master dissertation, Department of English, University of Ibadan).

Moore, G. (2000). Seven African writers. London: OUP.

Palmer, E. (1979). The growth of the African novel. London: Heinemann Educational Books Ltd..

Palmer, E. (Spring 1974). The criticism of African fiction: Its nature and function. In International fiction review (pp. 112-119). International Fiction Association.

Said, E. (1993). Culture and imperialism. New York: Vintage Books.

Ngugi, W. T. (1981). Writers in Politics. London: Heinemann Educational Books Ltd.. 
Ngugi, W. T. (1986). Decolonising the novel. Nairobi: East African Educational Publishers Ltd..

Ngugi, W. T. (1989). Petals of blood. London: Heinemann Educational Books. 